2. "For pain in the eye. A cauterizing in the hollow under the eyebrow and another at the nape of the neck; and that is good for catarrh of the head."

3. "For red watering eyes. ${ }^{(b)}$ Place a seton under the two jaws and a cautery at the nape of the neck; and that is good for a running from the head."

4. "For severe dryness of the lids. (c) Take the juice of strawberries, the fat of a fowl, and May butter; press them together and place them in a horn, and when thou goest to sleep anoint thine eyes and thy lids well, and they will be healed."

5. "There are seven enemies to the eye : Weeping, watching, a growth, intoxication, adultery, a dry film, and smoke."

6. "For a film on the eye. Let the juice of ground-ivy be placed in it, and the film will break and the eye will be well and bright."

7. "The small boy who persistently cries. Anoint the two supraciliary ridges with the bone-marrow of a deer, and less frequent will be the weeping."

Among directions for maintaining health during each month of the year:

8. "Month of February. Bleed the thumb of the left hand. Obtain a salve and a draught, and that will keep the eyes well."

9. "For a film on the eye. Put in it the juice of ground-ivy."

A Latin fragment is attached to the text. In this is found:

"The juice of wormwood taken with honey and vinegar is useful to the sight, and makes the eyes clear."

\title{
Yours truly,
}

STOCKPORT.

G. ApThomas.

P.S.- (a) Diverres. Le plus ancien texte des Meddygon Myddfeu, published by le Dault, Paris, 1913. Diverres takes (b) to refer to dacryocystitis, and (c) to blépharite glandulo-ciliaire.

\section{OBITUARY NOTICE}

David Charles Lloyd Owen, M.D., F.R.C.S.I., for many years a member of the honorary staff of the Birmingham Eye Hospital and a leading ophthalmic surgeon in the Midlands, died suddenly on Christmas night after a short illness, at the age of 82 years. His death took place at his home at Bron-y-Graig, Harlech, where for some years he and Mrs. Lloyd Owen, who died in the autumn of 1924, had lived with their elder married daughter and her husband, Colonel George Lloyd.

Born in 1843, a son of the Rev. D. Owen originally of Darowen, Montgomery, Lloyd Owen received his medical education at the 
Sydenham College and General Hospital, Birmingham. Qualifying in 1865, he held for two years the house-surgeoncy of the Eye Hospital, at that time a one-man post. Five years later, having in the meantime engaged in general practice, studied for a time in Paris, and been appointed ophthalmic surgeon to the Children's Hospital, he was elected an honorary surgeon to the Eye Hospital. (The writer of this note was the house surgeon of the hospital at that time.) Having a knowledge of refractive errors and skill in the use of the ophthalmoscope, which the seniors of those days had not acquired, being an excellent operator, and a particularly resourceful prescriber, he soon obtained high repute. Personally he was a charming man with a kindly genial manner, plenty of humour, and a handsome and expressive face. He formed many lifelong friendships in Birmingham.

Lloyd Owen joined the profession early enough to be intimate with Richard Middlemore in that veteran's later years. He was an original member of the Ophthalmological Society of the United Kingdom and one of its vice-presidents; one of the founders and the first president of the Midland Ophthalmological Society; and at one time president of the Midland Medical Society. He was a Knight of Grace of the Order of St. John of Jerusalem, and Vice-Chairman of the British Ophthalmic Hospital at Jerusalem. Though a great reader in several languages, and specially interested in the history of medicine, he wrote little. His chief contributions were a translation of Giraud-Teulon's "Function of Vision and its Anomalies" (1880) in which the characteristic lucidity of the French is admirably reproduced, a small volume on "Ocular Therapeutics" (1890), his Middlemore Lecture on "Pain in Eye Disease, its Character and its Relief" (1896), and the memoir of Richard Middlemore (1920), (Brit. Jl. of Ophthal., Vol IV, p. 49).

In 1898, when his period of active service at the Eye Hospital ended, he accepted the position of ophthalmic surgeon to the General Hospital, where the duty was chiefly consultative and much less arduous, and this he held till 1913.

Outside his profession also he had many activities and interests. He was a Justice of the Peace for the County of Warwick and the Borough of Sutton Coldfield, a prominent Freemason, a Positivist, a one-time president of the Birmingham Cosmopolitan Club, a student of Esperanto, and an archeoologist. He founded the Birmingham Welsh Society and on retiring to Wales was presented with a replica of the presidential badge. His last few years were spent in the lovely surroundings of his Welsh home, where from a delightful hillside garden backed by great rocks and traversed by a mountain stream he could enjoy a glorious view of Snowdon and the neighbouring mountains. Here the writer had the pleasure of visiting him in the autumn of 1924 . 